\title{
Understanding of the \\ Risk perception, Behavior, and Attitudes \\ Related to Smoking \\ among Cancer Patients: A Qualitative Study
}

\author{
Dr William HC LI, Dr. K.Y HO, Prof T.H. LAM \\ School of Nursing, \\ The University of Hong Kong \\ Abstract number: MSCC8-0913
}

\section{Introduction}

Cigarette smoking can lead to many types of cancer. Cancer patients who smoke are at greater risk of poor prognosis, metastasis, recurrence and even mortality than those who do not smoke. Nevertheless, many of these smoking patients are reluctant to quit and continue to smoke after receiving a cancer diagnosis.

\section{Objectives}

This qualitative study aimed to understand the needs and concerns of smoking cancer patients. Particularly, their risk perceptions, behaviors and attitudes related to smoking were explored.

\section{Methods}

Subject recruitment was conducted in an oncology ward of a public acute care hospital in Hong Kong. Patients who were newly diagnosed with cancer were invited for a one-to-one semistructured interview. Data was saturated after 40 patients (20 current smokers and 20 ex-smokers) were interviewed.

\section{Results}

From September 2012 to January 2013, we identified 241 patients who were smokers prior to their cancer diagnosis. Of these patients, 208 (86.3\%) quitted smoking, but 33 (13.7\%) continued their smoking habit after the diagnosis. Cancer patients who continued to smoke, in general, regarded that the benefits of smoking outweighed its adverse effects on their health. Whereas those abstained from cigarette perceived that the benefits of quitting far outweighed the disadvantages.

\section{Conclusion}

Helping cancer patients to quit smoking is one of the unshrinkable responsibilities of healthcare professionals. A thorough understanding of the risk perceptions, behaviors and attitudes towards smoking among cancer patients will contribute to the development of effective smoking cessation interventions.

\begin{tabular}{|c|c|c|c|c|}
\hline \multirow[t]{2}{*}{ Theme } & \multicolumn{2}{|r|}{ Current smoker } & \multicolumn{2}{|r|}{ Ex-smoker } \\
\hline & Category & Sample quotation & Sub-categories & Sample quotation \\
\hline \multirow[t]{3}{*}{$\begin{array}{l}\text { Knowledge of the } \\
\text { association between } \\
\text { smoking and cancer }\end{array}$} & $\begin{array}{l}\text { Cancer is not attributable to } \\
\text { smoking }\end{array}$ & $\begin{array}{l}\text { "Those friends of mine who developed cancer weren't smokers. } \\
\text { In contrast, the others who smoke three to four packs of } \\
\text { cigarettes a day are in perfect shape." }\end{array}$ & \multirow[t]{3}{*}{$\begin{array}{l}\text { Smoking can cause } \\
\text { cancer }\end{array}$} & \multirow[t]{3}{*}{$\begin{array}{l}\text { "I think smoking and cancer are related, that's why I quit } \\
\text { smoking right after my cancer diagnosis." }\end{array}$} \\
\hline & Cancer is attributable to fate & $\begin{array}{l}\text { "I think everything is determined by fate, including my cancer, } \\
\text { which is unpreventable. It is not a matter of whether I } \\
\text { continued smoking or not." }\end{array}$ & & \\
\hline & $\begin{array}{l}\text { Smoking has no effect on } \\
\text { cancer prognoses }\end{array}$ & $\begin{array}{l}\text { "I have tried ceasing smoking for a week, but the cancer index } \\
\text { still went up" }\end{array}$ & & \\
\hline \multirow[t]{3}{*}{$\begin{array}{l}\text { Reasons for continuing } \\
\text { smoking/quitting }\end{array}$} & $\begin{array}{l}\text { Moderate smoking causes no } \\
\text { harm }\end{array}$ & $\begin{array}{l}\text { "What I strongly believe is that I only smoke four sticks per } \\
\text { day, and it won't hurt me that much!" }\end{array}$ & $\begin{array}{l}\text { Health and } \\
\text { treatment efficacy }\end{array}$ & $\begin{array}{l}\text { "I know smoking is hazardous to my health. I already got } \\
\text { cancer; I don't want my health to get worse, that's why I } \\
\text { quit smoking." }\end{array}$ \\
\hline & $\begin{array}{l}\text { Desensitized to tobacco } \\
\text { smoke }\end{array}$ & $\begin{array}{l}\text { "As we already have such a long smoking history, our body is } \\
\text { already desensitized to tobacco smoke." }\end{array}$ & \multirow[t]{2}{*}{ Family support } & \multirow[t]{2}{*}{$\begin{array}{l}\text { "My wife and my sons often advised me to quit after I got } \\
\text { the cancer. Indeed, without their support, I don't think I } \\
\text { could have quit smoking successfully." }\end{array}$} \\
\hline & It is too late to quit & $\begin{array}{l}\text { "The doctor told me that my cancer is now at stage IV and the } \\
\text { disease can't be cured. I am expected to survive for another } \\
\text { three months... what can I do? It's too late to quit." }\end{array}$ & & \\
\hline \multirow[t]{3}{*}{$\begin{array}{l}\text { Perceived barriers / } \\
\text { benefit to quitting }\end{array}$} & $\begin{array}{l}\text { Quitting could harm the } \\
\text { physical health }\end{array}$ & $\begin{array}{l}\text { "Those who quit got diseases right away, and just died right } \\
\text { away: this is what I witnessed." }\end{array}$ & Better prognosis & $\begin{array}{l}\text { "The doctor and nurses told me that quitting smoking can } \\
\text { improve the cancer prognosis, that's why I quit." }\end{array}$ \\
\hline & $\begin{array}{l}\text { Quitting could remove the } \\
\text { psychological benefits of } \\
\text { smoking }\end{array}$ & $\begin{array}{l}\text { "I am not considering quitting smoking right now as it helps } \\
\text { me cope with stress and relieves my boredom." }\end{array}$ & \multirow[t]{2}{*}{ Saving money } & \multirow[t]{2}{*}{$\begin{array}{l}\text { "I have lost my job since I got cancer. I can't afford to buy } \\
\text { two packs of cigarettes a day any more. Anyway, quitting } \\
\text { can at least help me save some money." }\end{array}$} \\
\hline & $\begin{array}{l}\text { Social and interpersonal } \\
\text { factors }\end{array}$ & $\begin{array}{l}\text { "My colleagues sometimes give me cigarettes, and I don't } \\
\text { know how to refuse them. I accept the cigarettes out of } \\
\text { courtesy." }\end{array}$ & & \\
\hline
\end{tabular}

\section{Practice Implications}

Understanding how current smokers and ex-smokers perceive the risks of smoking, and their behavior, attitudes, and experiences related to smoking is an essential prerequisite for the design of an effective and appropriate smoking cessation intervention that can help cancer patients achieve a greater level of smoking abstinence and a lower level of relapse. Moreover, the results of this qualitative study can guide the development of protocols and interventions that will demystify the misconceptions about smoking among current smokers, increase their perception of the risks of continued smoking and benefits of quitting. Additionally, it is crucial to motivate more healthcare professionals to assess health behaviors of smoking cancer patients and to implement evidence-based interventions to help them quit smoking. Most importantly, healthcare professionals should be offered relevant training so as to enhance their self-efficacy and confidence in promoting smoking cessation to cancer patients. 